\title{
A review of methods and models of technology transfer
}

\author{
Zahra Farhadikhah $^{1^{*}}$, Sayed Mohamad Hasan Husseini ${ }^{2}$ \\ ${ }^{1}$ Department of Industrial Management, Shahrood University, Shahrood, IRAN \\ ${ }^{2}$ Assistant Professor, Department of industrial engineering, Shahrood University, Shahrood, IRAN \\ E-mail address: Z.farhadi2012@yahoo.com
}

Keywords: Technology, Technology components, Technology transfer.

\begin{abstract}
Technology transfer is a complex and sensitive process, if not conducted through awareness and research will entail hefty and immense costs and losses. Since the audience of this process are mostly in developing countries, it can be stated that studying and investigating the trend of most technologies transferred to the developing countries commonly indicates the weaknesses that due to unawareness of the conditions and existing needs and also policies and objectives the technology transferors follow could lead to irreparable failures, thus inhibiting the applicant from accessing the technology itself. The importance of technology transfer and its role in the industrial development of countries and filling of the technology gap between the developing and developed countries is inevitable. Technology transfer is conducted in various ways based on the conditions of the receptors and donors of technology. In this paper, the process of technology transfer and types of relevant methods that would lead to effective technology transfer are going to be elaborated. Also, models related to technology transfer will be examined.
\end{abstract}

\section{INTRODUCTION}

Through studying the records of developing countries, particularly the South East countries in Asia, it is observed that they, during the course of development have reinforced the foundation of their own countries technologies through its transference from other developed countries and thereafter via creation of appropriate economic infrastructure, they have embarked on enhancing their own academic and research centers. If developing countries intend as another solution to acquire necessary scientific and technologic knowledge for the sake of economic boom without utilizing existing knowledge which is a consequence of researches by researchers and scholars across the world, this will not only be a difficult problem, but it will also result in irrational wastage of sources and forces. On the other hand, having access to such a goal in a short period of time will be impossible. Hence, to reduce technology distance between developing and developed countries, transferring scientific and technologic knowledge will be the best option.

\section{Technology definitions}

Technology could be defined as all knowledge, products, processes, means and ways and systems which are utilized for creation and manufacturing of goods and services. Put it simply, technology is the way we do things (Khalil, 2002). The England's National Education Council has defined technology as the creative application of the knowledge of concepts and necessary experience for designing and manufacturing of high quality products. For the European IndustrialResearch Association, technology is a means wherebyknowledge, science and discoveries are applied for producing goods (Akhavan, 1999). According to the United Nations Industrial Development Organization, technology is referred to necessaryknowledge and techniques for certain goods and services which are obtained as a result of thinking power and human awareness as well as combination of existing natural laws and in a broadersense, it comprises the application of sciences in industry by using targeted and regular methods and studies (UNIDO 1989). Simply, technology means technical knowledge that deals with fusion of the processes of production and designof products, understanding of material and controlling of quality. 


\section{Technology transfer definitions}

People have different takeaways of the concept of technology transfer. Acquisition of technology in production firms will only be possible through technology transfer, either vertical transfer or horizontal transfer. In the vertical research and development transfer, technical information and applied research findings will be transferred to a development and engineering design stage and then enter into the production process as technology becomes commercial. In the horizontal transfer, technology is transferred from an ability level in a country or another corporation to the same level of ability in another location (Banavand, 2007). Through this preamble, several definitions of technology transfer will be reviewed. Technology transfer means using existing technology in a place where it has not been previously used (Malekifar and Tabatabian, 2003). In 1996, Brooks stated the first definition of technology transfer as this: a process in which a form of technology and knowledge are disseminated through human conducts and activities (Brooks, 1966). Technology transfer is a regular process or cycles of purposeful activities through which a set of technology elements will be applied in a place other than the primary place where technology was created. Technology transfer as a business is once accomplished when all these elements are transferred and used optimally (Aghaee, 1989). Technology transfer, for NASA refers to a process during which it is possible to apply the technology of a country or organization in another country or organization (Khalil, 2009).

\subsection{Types of technology transfer}

International technology transfer: a state in which the act of transfer will cut across national borders, e.g. technology transfer from industrial countries to developing countries

Regional technology transfer: a state in which technology in one single country is transferred from a region to another region, e.g. in the United States from Florida to Alaska

Inter-industry technology transfer: a state in which technology is transferred from an industry to other industries, e.g. technology transfer from a space program to commercial uses

Inter-corporate technology transfer: a state where technology is transferred from one corporation to another corporation (Berman and Khalil, 1992).

\subsection{Types of methods for technology transfer}

By technology transfer methods, it is a series of pre-defined activities through which the technology needed is made available to the applicant. In the following, the most significant ways for technology transfer are cited.

1. Faulty technology transfer: Here, at first, technology is placed on the course of production and then it is gradually transferred to research centers for the sake of using the results in the area of production at some appropriate time.

2. Incomplete transfer or independent way: in this state, technology which has grown in research centers will gradually end up in the production level. This method will take some long time.

3. Full technology transfer: this method is a combination of the two previous methods in which technology for the first time is simultaneously used in research centers and in production and research centers attempt to expand and improve the production through innovation.

4. Commercial technology transfer: In this method, after the depreciation $f$ the technology which enters into production directly will be replaced by some new technology. Research institutions will have no role in this regard (Attaran, et al 2014). 


\begin{tabular}{|l|l|c|l|}
\hline 1 & Direct foreign investment (FDI) & 10 & Cooperation \\
\hline 2 & Transfer through franchise or license & 11 & Mutual purchase contracts \\
\hline 3 & Joint investment(JV) & 12 & $\begin{array}{l}\text { Recruitment of technical and scientific } \\
\text { personnel }\end{array}$ \\
\hline 4 & Turn Key contracts (Turn-key) & 13 & Consortium \\
\hline 5 & Contract for research and development & 14 & Stocks appropriation \\
\hline 6 & Reverse engineering & 15 & Training and acquisition of skills \\
\hline 7 & Networking & 16 & $\begin{array}{l}\text { Importation of machinery and investment } \\
\text { goods }\end{array}$ \\
\hline 8 & Cash aids contracts & 17 & $\begin{array}{l}\text { Holding conferences a d expos of books } \\
\text { and publication of papers a d international } \\
\text { trade and industrial exhibitions }\end{array}$ \\
\hline 9 & Subsidiary and second hand contracts & & \\
\hline
\end{tabular}

The degree to which each of the technology transfer methods is significant and rated depends on such factors as the nature of technology in use and the capacity and ability of the country receiving technology for learning and attracting technical and technologicknowledge (Hodavand, 2006).

\section{Process models of technology transfer}

This model indicates that the process of technology transfer involves 6 general phases: phase 1, selection and acquisition of technology: process of technology selection from among existing technologies and negotiation and finalization of contracts for its acquisition; phase 2, adaptation of imported technology: process of close linkage of imported technology with the needs of the scheme and the sources and conditions of the country; phase 3, attraction of imported technology: process of full awareness of the receptor towards all the components of the technology acquired; phase 4, application of transferred technology: process of utilization of acquired technology; phase 5, expansion of imported technology: process in which using the technology acquired, the knowledge resulting from its adaptation, attraction and application, experience, skills and findings of internal researches, the technology will expand for the processes and better process; phase 6, dissemination of imported technology: process of deepening and expansion of components of the technology acquired at the national level.

The following graph illustrates the conceptual model of the technology transfer process (Nazemi, 2011).

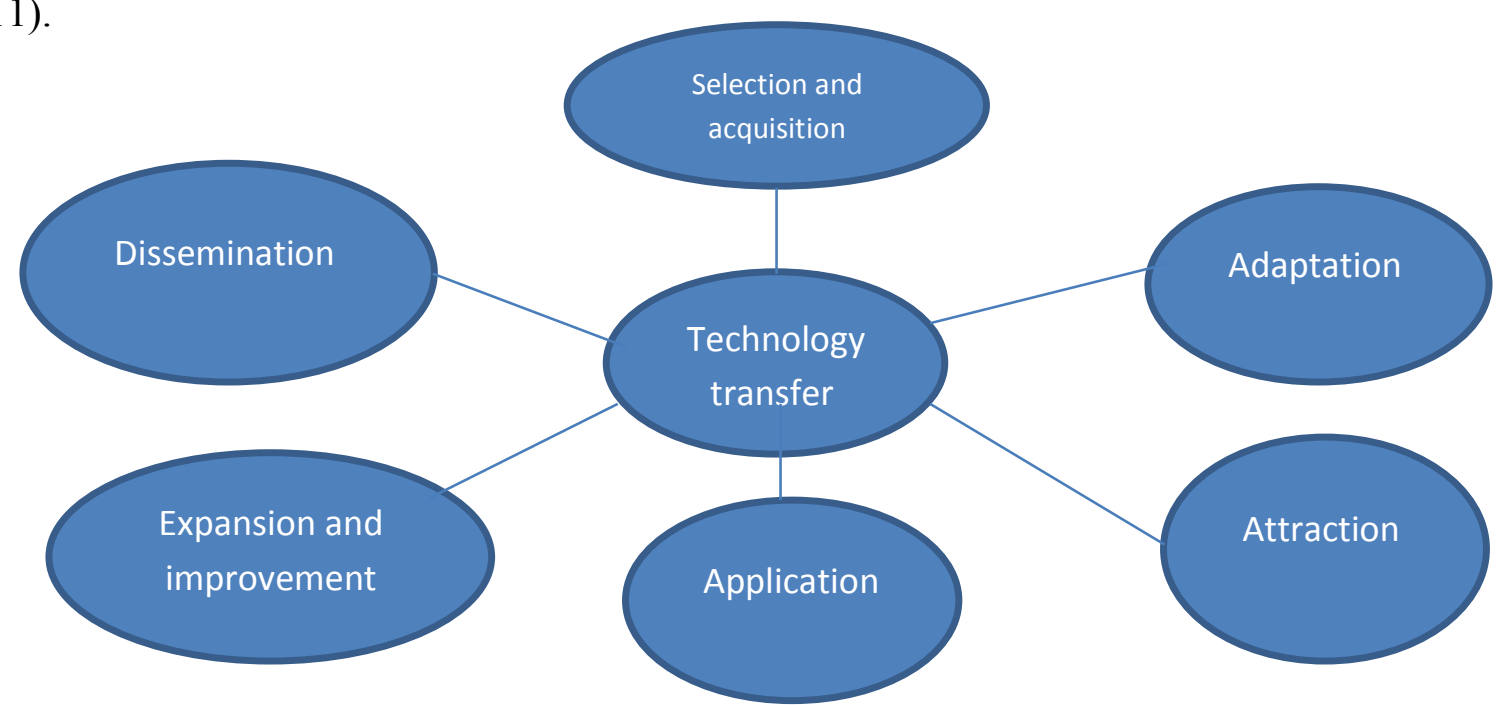




\subsection{Categorization of technology transfer models}

Samli Kaskone states the process of technology transfer involves various, numerous and highly complex dimensions that some of its dimensions contradict the others. The complexity of the technology transfer process has caused various models to be raised in this regard. Hence, the next section will discuss the elaboration of the most important models raised in the area of technology transfer.

Chiesa model: It is one of the most complete models in the area of selection of technology based collaboration method has been presented by Chiesa in which such factors as cooperation, familiarity with technology and market and several more factors have been considered. In this model, some dimensions have been considered for each factor and given this character which contains the donor and receptor of technology and the technology itself, the appropriate methods for technology transfer has been introduced (Chiesa and Manzini, 1998).

\begin{tabular}{|c|c|c|}
\hline Factors & Levels and conditions & Model recommended method \\
\hline \multirow[t]{3}{*}{ Goal of cooperation } & Broad & Creation of a joint commercial unit \\
\hline & Limited and definite & outsourcing-alliance \\
\hline & Maximizing learning & $\begin{array}{l}\text { Creation of a joint commercial } \\
\text { unit-alliance }\end{array}$ \\
\hline \multirow{2}{*}{$\begin{array}{l}\text { Definition of cooperation } \\
\text { provisions }\end{array}$} & Strong & - \\
\hline & Weak & $\begin{array}{l}\text { Cooperation in the area of research } \\
\text { and development of alliance }\end{array}$ \\
\hline \multirow{3}{*}{$\begin{array}{l}\text { Understanding technology } \\
\text { and market }\end{array}$} & Non-familiarity with both & Training and education \\
\hline & $\begin{array}{l}\text { Understanding the market } \\
\text { or understanding the } \\
\text { technology }\end{array}$ & $\begin{array}{l}\text { Creation of a joint commercial } \\
\text { unit-alliance }\end{array}$ \\
\hline & $\begin{array}{l}\text { Understanding the market } \\
\text { and technology }\end{array}$ & Acquisition of corporate ownership \\
\hline \multirow[t]{2}{*}{ Life span of technology } & Puberty & outsourcing \\
\hline & Emergence & Stocks appropriation \\
\hline \multirow{2}{*}{$\begin{array}{l}\text { Innovation stage in the } \\
\text { transfer process }\end{array}$} & Initial & outsourcing -Alliance \\
\hline & Final & outsourcing \\
\hline \multirow[t]{2}{*}{ Investment divisibility } & Low & Creation of a joint commercial unit \\
\hline & High & $\begin{array}{l}\text { Creation of a joint commercial } \\
\text { unit-alliance }\end{array}$ \\
\hline \multirow{2}{*}{$\begin{array}{l}\text { Communication with the } \\
\text { organization }\end{array}$} & Horizontal & outsourcing -Alliance \\
\hline & Vertical & $\begin{array}{l}\text { Creation of a joint commercial } \\
\text { unit-alliance }\end{array}$ \\
\hline \multirow[t]{2}{*}{ Risk level } & High & - \\
\hline & Low & - \\
\hline \multirow[t]{2}{*}{$\begin{array}{l}\text { Ability to maintain and } \\
\text { preserve technology }\end{array}$} & Great & $\begin{array}{l}\text { Acquisition of } \\
\text { integration }\end{array}$ \\
\hline & Low & $\begin{array}{l}\text { Acquisition of } \\
\text { integration }\end{array}$ \\
\hline \multirow[t]{2}{*}{ Investment level needed } & High & - \\
\hline & Low & - \\
\hline \multirow{2}{*}{$\begin{array}{llr}\text { Source } & \text { country } & \text { of } \\
\text { technology } & \text { from cultural } \\
\text { point } & & \end{array}$} & Similar & outsourcing \\
\hline & Different & - \\
\hline
\end{tabular}




\begin{tabular}{|l|l|ll|}
\hline $\begin{array}{l}\text { Area of activity of the } \\
\text { technology source }\end{array}$ & Similar & outsourcing \\
\cline { 3 - 4 } & Different & - & \\
\hline $\begin{array}{l}\text { Size and power of } \\
\text { technology source }\end{array}$ & Similar & $\begin{array}{l}\text { Acquisition of } \\
\text { integration }\end{array}$ & \\
\cline { 2 - 4 } & Different & - & \\
\hline
\end{tabular}

Robert Wand Berry model: In this model, different strategies are considered for acquiring technology in order to enter into a new commerce. Two factors of interest in this model are:

Degree of the company's familiarity with the market

- Basic market: The company's current market

- New and known market: The products of this market have not yet entered into this market, however, there is enough familiarity with it.

- New and unknown market: No market has ever existed for the technology product and there is a need for such a market by the company; or the market has previously existed, however, there is no enough information regarding it.

Degree of the company's familiarity with the technology

- Basic market: There is technology in the company

- New and known market: The products of this market have not yet entered into this market; however, there is enough familiarity with it.

- New and unknown market: No technology already existed and it is unknown.

Of the combination of these factors, a matrix of 9 entries is obtained where in each of the entries he way cooperation is related with two attributes specific of the market and technology could be witnessed (Robert and Berry, 1985).

\begin{tabular}{|c|c|c|c|c|}
\hline & $\begin{array}{ll}\text { New and } \\
\text { unknown }\end{array}$ & $\begin{array}{l}\text { Stocks } \\
\text { appropriation } \\
\text { Training and } \\
\text { education }\end{array}$ & $\begin{array}{l}\text { Stocks appropriation } \\
\text { Training and } \\
\text { education }\end{array}$ & $\begin{array}{l}\text { Creation of a joint } \\
\text { commercial unit }\end{array}$ \\
\hline \multirow[t]{3}{*}{ Market status } & $\begin{array}{l}\text { New and } \\
\text { known }\end{array}$ & $\begin{array}{l}\text { Stocks } \\
\text { appropriation } \\
\text { Training and } \\
\text { education }\end{array}$ & $\begin{array}{l}\text { Acquisition of the } \\
\text { company's } \\
\text { ownership } \\
\text { Purchase of the } \\
\text { franchise }\end{array}$ & Appropriation \\
\hline & Basic & $\begin{array}{l}\text { Creation of a } \\
\text { joint } \\
\text { commercial } \\
\text { unit }\end{array}$ & $\begin{array}{l}\text { Acquisition of the } \\
\text { company's } \\
\text { ownership } \\
\text { Purchase of the } \\
\text { franchise }\end{array}$ & $\begin{array}{l}\text { Endogenic } \\
\text { development } \\
\text { (along with } \\
\text { appropriation) }\end{array}$ \\
\hline & & Basic & New but known & $\begin{array}{l}\text { New } \\
\text { unknown }\end{array}$ \\
\hline
\end{tabular}

Technology status 
Ford's model

This model presented by Ford introduces five factors as effective factors in selecting technologic cooperation method which are:

- Relative status of the company in connection with the technology: if the relative status of a company is higher in relation with technology, the company had better invest on its strong point and design and produce new technologies inside the organization. However, should the position of the company in terms of technology is at a lower level, it is better to purchase it.

- Immediacy of access to technology: If we desire to rapidly access some technology, purchasing the technology or purchasing the right to use it immediately is superior to internal research and development which is time consuming.

- Dependency on technology/necessary investment: this will establish balance points in the direction of methods related with important and unimportant technologies.

- Situation of the cycle of technology life: Older technologies are thought to be having more chance in direction of external acquisition compared to newer technologies.

- Categorization and types of technology: The technologies applied are divided into three categories in producing the product. First, the basic technologies without which the company will not be able to continue its operation in the market. For instance, in the company "Black and Decker", this technology is equivalent to small manual devices within production technologies. However, the said company is beliv3d to be the maker of the highly complex electric engines in the world. This ability creates the second group of technology named Superior Technology which is concentrated in this company. Some of other aspects of production like plastic parts or some of the painting works in this company constitute the third category which is external technologies (Khalil, 2009).

\begin{tabular}{|l|l|l|l|l|l|}
\hline $\begin{array}{l}\text { Effective } \\
\text { factors }\end{array} / \begin{array}{l}\text { Relative } \\
\text { status of } \\
\text { the } \\
\text { company } \\
\text { in relation } \\
\text { with the } \\
\text { company } \\
\text { Access } \\
\text { of access to }\end{array}$ & $\begin{array}{l}\text { Immediacy } \\
\text { technology }\end{array}$ & $\begin{array}{l}\text { Dependency } \\
\text { on tech/ } \\
\text { necessary } \\
\text { investment }\end{array}$ & $\begin{array}{l}\text { Status of the } \\
\text { Technology } \\
\text { life span }\end{array}$ & $\begin{array}{l}\text { Categorization and } \\
\text { types } \\
\text { technology }\end{array}$ \\
\hline $\begin{array}{l}\text { Internal } \\
\text { research and } \\
\text { development }\end{array}$ & High & Lowest & Highest & Earliest & $\begin{array}{l}\text { Most prominent or } \\
\text { critical }\end{array}$ \\
\hline Joint activities \\
\hline $\begin{array}{l}\text { outsourcing of } \\
\text { research and } \\
\text { development }\end{array}$ & Lower & Low & Early & Prominent or basic \\
\hline $\begin{array}{l}\text { Acquisition of } \\
\text { the right to use } \\
\text { technology }\end{array}$ & High & Early & Prominent or basic \\
\hline $\begin{array}{l}\text { Lack of access } \\
\text { (Production of } \\
\text { final product } \\
\text { or production } \\
\text { of part of it) }\end{array}$ & Low & High & Late & Prominent or basic \\
\hline
\end{tabular}


Gilbert's model: In this model, transfer methods are grouped in four:

- Inactive methods: the receptor will inactively acquire the technology required under some certain conditions

- Cooperation method: the holder and receptor of the technology will have some active role in technology transfer

- Anti-competitive methods: Technology required will be acquired without notification and consent of the technology holder

- General method: The required knowledge and skills will be obtainedthroughparticipation in educational courses (Lee, 1998).

\begin{tabular}{|l|l|l|l|}
\hline $\begin{array}{l}\text { Does the receptor } \\
\text { have the ability to } \\
\text { secure the } \\
\text { requirements } \\
\text { made by the } \\
\text { holder of the } \\
\text { technology? }\end{array}$ & $\begin{array}{l}\text { Yes } \\
\text { Purchase of technology methods } \\
\text { products } \\
\text { Purchase of the franchise } \\
\text { Franchise }\end{array}$ & $\begin{array}{l}\text { Cooperation method } \\
\text { outsourcing Purchase of } \\
\text { the franchise jointly } \\
\text { Stocks appropriation } \\
\text { Creation of a joint } \\
\text { commercial unit } \\
\text { Acquisition of the } \\
\text { company's ownership } \\
\text { Integration }\end{array}$ \\
\cline { 2 - 3 } & No & $\begin{array}{l}\text { General methods } \\
\text { Training and education } \\
\text { Recruitment and exchange } \\
\text { of human force }\end{array}$ & $\begin{array}{l}\text { Anti-competitive } \\
\text { Imitation } \\
\text { Industrial espionage } \\
\text { Copying }\end{array}$ \\
\hline
\end{tabular}

Does the receptor of technology have control over the way technology is used?

Tidd and et al Model: Tidd has paid attention to two factors of the organization's attributes in one of his own models and expresses his own model as following:

\begin{tabular}{|l|l|l|}
\hline Method & Cost of acquisition & Learning potential \\
\hline License & Low & Low \\
\hline Purchase of equipment & Average & Low \\
\hline $\begin{array}{l}\text { Second hand and subsidiary } \\
\text { contracts }\end{array}$ & Average & Low \\
\hline FDI & Average & Average \\
\hline External provision & Average & Average \\
\hline $\begin{array}{l}\text { Utilization of people just } \\
\text { returned to the country }\end{array}$ & Average & High \\
\hline $\begin{array}{l}\text { Strategic contracts/Joint } \\
\text { investment }\end{array}$ & Average & High \\
\hline $\begin{array}{l}\text { Production of original } \\
\text { products (OEM) }\end{array}$ & High & High \\
\hline $\begin{array}{l}\text { Acquisition from foreign } \\
\text { countries }\end{array}$ & High & High \\
\hline Research and development & High & High \\
\hline
\end{tabular}

In this model, Tidd has raised two factors of cost of acquisition and learning potential and considered transfer methods based on these two factors (Tidd and Trewhella, 1997). 
Obstacles to technology transfer in Iran

In the last fifty years, over 300 billion dollars have been spent buying machinery and spare parts and equipment where part of this revenue has been set aside for establishing research and development centers and educating the expert human force. However, after fifty years of immense investment on creating and putting up different industries, we should have been able to design and manufacture all these industrial equipment and machinery (Tavakoli, 2001), whereas it has not been the case and the country has not self-sufficiency in manufacturing refineries and power stations. Obstacles to technology transfer vary in Iran but the above deterrent factors could be divided into two categories. The first category includes macroeconomic factors while the second group involves lack of investment in research and development (Malekifar and Tabatabian, 2003). Obstacles to technology transfer in Iran are as follow:

Lack of expert force (Akhavan, 2000)

Lack of investment and financial credits (Arabi, 2007)

Abstaining from providing technologies by the countries holding and owning such technologies

Non-investigation of the role of technical and professional training in the process of technology transfer (Rezaie, 2003)

Non-expansion of financial support (Shahidi, 1991).

\section{CONCLUSION}

Generally, developing countries could learn valuable lessons from the successful experience of some of the industrial and newly industrialized countries, particularly the countries located in south eastern part of Asia and the Latin American countries within the direction of technology and industry. The successful experience of thesecountries has shown that learning and transferring of technology at large scales have enabled these countries to add to their own productivities and as a result, this has led to their ever increasing industrial growth. For instance, such countries like South Korea, Taiwan and Mexico have been made known to the world mostly through imports and transfer of technology. Generally speaking, success factors of these countries could be divided into two internaland external factors. Inside these countries, the national determination has been made for expansion of technology and technology has been on top of all priories for all planning and measures and all the ground has been prepare for the fulfillment of this agenda. Externally, due to saturation of the investment environment in advanced countries, western countries and companies as well as international bodies have been inclined to joint investment and jointventures inthese countries. Although these countries could be distinguished from other nations due to some macro economic features like per capita income and economic volume and primary sources and the industrialization trend, investigation of these successful factors would be so much helpful for developing countries to experience advancement.

\section{References}

[1] Khalil, T. (2004), Technology management (Key to success in competition an creation of wealth), Tehran: Bureau of cultural research

[2] Aghaee, M. (1989), Contracts of technology transfer. Journal of research in sciences and industry, 8(17): 18-31

[3] Hodavand, M. (2006). Technology transfer contracts. Journal of foresight, 17(167): 42-48.

[4] Akhavan, A. N. (2000). "subject abut technology transfer", Tehran, R\&D, university institute industrial engineer Tehran. 
[5] Malekifar, Aghil \& Tabatabaian, Kamal. (2003). "base of technology \& technology transfer at of desire policy-making for development of technology", Tehran: publishing study \& research institute.

[6] Brooks, H. (1966). National science policy and technology transfer, Proceedings of the Conference on Technology Transfer and Innovation, National Science Foundation, US Government Printing Office, Washington DC, USA.

[7] Berman, E.M \& Khalil. T. (1992). "Technological competitiveness in the Global Economy." A survey international of Technology Management, 7: 346-358.

[8] Nazemi,Sh. (2011). Considration Of Technology Transfer Changes In The Field Of Pharmaceutical Biotechnology In Iran Towards Pattern Recognition, Department of Technology Management, Islamic Azad University, Science \& Research Branch.

[9] Chiesa, V. \& Manzini, R. (1998). Organizing forTechnology Collaborations: AManagerial,Vol Perspective, R\&D managem, 28(3): 199-212.

[10] Robert, E. and Berry, C. (1985). Ent new businesses: selecting str for success, Sloan Manageme Review, pp. 73-84.

[11] Khalil, T. (2009). Management ofTechnology: The Key to Competitiveness and Wealth Creation Mc Graw Hill, New York, USA.

[12] Lee, G.A. (1998). Negotiating technology acquisition: getting tools you need to succeed, Working Paper, Nanyang Technology University.

[13] Tidd, J., Bessant, J., \& Pavitt, K. (2001). Managing Innovation: Integrating Technological, Market and Organisational Change, 2nd ed. Wiley, Chichester.

[14] Tidd, J., \& Trewhella, M. (1997). Organizational and Technological Antecedents for KnowledgeAcquisition and Learning,R\&D Management. 27(4): 359-375.

[15] Tavakoli, Alireza (1379), "suitable method in technology transfer to Iran A.M dissertation, university of politechnique Iran.

[16] Arabi, Abdulhamid (1386), "effective method technology transfer", A.M dissertation, azad university, Tehran.

[17] Rezaie, A. (2003). "study of technolog ransfer methods \& suggesting an appropriate \& effective method for Irazz.

[18] Shahidi, M. T. (1992). echnology transfer \& to industrialize eveloping country". Tehran: publishing Tehran niversity.

[19] Attaran, R., \& Mehrmanesh, H., \& Jafarieh, H. (2014). "An ANP application for identifying and prioritizing opportunities and threatens for technology transfer",Decision Science Letters, 3: 85-92. 